\title{
THE UNION TRADE COMPANY AND ITS RECORDINGS: AN UNINTENTIONAL DOCUMENTATION OF WEST AFRICAN POPULAR MUSIC, 1931-1957
}

\author{
Vert ARLt \\ CENTRE FOR AFrICAN STUdIES \\ UNIVERSITY OF BASEL
}

This paper introduces a unique collection of roughly 700 historical recordings of African popular music generated by a Swiss trading company, which today is located at the archives of mission 21 (formerly Basel Missioin) in Basel. The music was recorded and distributed by the Union Trade Company of Basel (UTC) during the 1930s and 1950s in the Gold Coast and Nigeria. The collection represents a rich resource for the study of African history and cultures and caters for the growing interest shown by social historians of Africa in everyday life and accordingly in leisure activities and consumption. ${ }^{1}$

As music and dance undoubtedly play an important role in African social and religious life, they have received much attention and there is a longstanding tradition of ethnomusicological research that has led to a great number of sound collections. The historian interested in the "modern" and "postmodern" or in popular culture, however, tends in many cases to be frustrated by the material contained in these archives. The ethnographic collectors often showed a blind eye to the modernizing forces within the African musical cultures they researched and concentrated on documenting what they perceived as the "original" or "traditional." 2 Furthermore the collection and documentation of the

1I use the plural when speaking on behalf of the project "Ghana Popular Music 1931 1957," on which I have been working together with the music journalist Serena Owusua Dankwa (www.unibas.ch/africanmusic) and I use the singular when referring to my authorship of this article. For an overview of recent work in the field see Emmanuel Akyeampong and Charles Ambler, "Leisure in African History: An Introduction," IJAHS 35(2002), 2.

${ }^{2}$ See for example Gaston Knosp, Enquête sur la vie musicale au Congo belge: 19341935 (Tervuren, 1968).

History in Africa 31 (2004), 393-405 
popular music of the day was rarely on the agenda of national research institutions and archives in postcolonial Africa. ${ }^{3}$ In the case of Ghana at least three initiatives have resulted in important collections of music that go beyond a narrow ethnographic documentation. The first, by Prof. Kwabena Nketia at the Centre of African Studies at the University of Ghana, features a mixture of field recordings and a few commercial records. ${ }^{4}$ The others focus specifically on the commercial and popular. These are the Gramophone Records Museum in Cape Coast, discussed below by its founder Kwame Sarpong and the Bokoor African Popular Music Archives Foundation (BAPMAF) of John Collins in Accra.

The collection of commercial UTC recordings located in Basel is an important addition to the three Ghanaian collections as it offers a unique cross-section through the music of Ghana and Nigeria, while at the same time it reflects the history of the UTC itself. The recordings are part of the Ghanaian and Nigerian national cultural heritage and should be preserved and be made accessible to researchers and music lovers. Even more important to us is the goal of rendering them accessible to the inhabitants of their countries of origin. 5 Since similar collections exist elsewhere, why should the recordings of the now defunct Union Trade Company be of special interest-what is the special quality of the collection? I will briefly discuss the history of the UTC itself in order better to understand its special character and sudden downfall. This will provide the necessary background to UTC's recording activities and help to comprehend the nature of the music recorded and the contents of the collection.

\section{II}

When the Union Trade Company of Basel ceased to operate in 1999, hardly anybody in Switzerland took notice of it beyond employees and stockholders. In Ghana, on the other hand, where the company's origins are to be traced and where it had played an important role in the economic and social history, many would not believe the news. UTC and its mother society the Basel (Mission) Trading Company had

\footnotetext{
3 Popular music is here understood as contrasting music connected to the practice of religion or court culture. In most cases its performance is connected to a commercial interest.

${ }^{4}$ See the compact disc "Music in Ghana. A Selection out of the Archives of African Music at the Institute of African Studies, University of Ghana, Legon" (Compact disc, popular african music pamap 601) (Mainz, 1997).

$5_{\mathrm{A}}$ pioneering project in this field is the pictorial collection of the former Basel Mission. 18,000 mostly photographic pictures are now accessible worldwide via the website www.bmpix.org.
} 
employed and trained generations of Ghanaians and had shaped their tastes as consumers. The UTC department store on High Street, Accra had been the first such store in the whole of west Africa and has become a landmark in the urban landscape of Accra, much like the smaller UTC stores have done in all parts of the country. UTC and "Basel Trading" were two well-known brand names in Ghana for some 150 years. They were among the major players doing business on the Gold Coast and later in independent Ghana. Their names stood for quality and straightforward trading and were closely connected to the work of the Basel Mission in Ghana, which in some respect offered the blueprint for the present system of education in Ghana.

The company had developed out of the commercial activities of this evangelical mission society on the Gold Coast. It was in 1855 that the mission board sent the young Hermann Ludwig Rottmann, son of a longstanding trading family from Hamburg-Altona, to the Gold Coast to handle the supply of the missionaries in the field with the necessary European goods. With his commercial training, Rottmann clearly saw the business opportunities on offer there. Soon after his arrival he opened a shop, where he traded European goods for African palm oil, cotton, hides, etc. Even though this activity deviated from the task he had been assigned by the mission's director, he was supported by some members of the mission board in Basel, most of them wealthy merchants and sensible to any such opportunity. With their financial investments, the small shop within a few years developed into a meaningful import-export business. In establishing powerful trade networks with the Gold Coast hinterland, Rottmann was greatly helped by his marriage with Regina Hesse, a preschool teacher of the Basel Mission who descended from a wealthy Euro-African merchant family of long standing, which provided access to far reaching and well-established trade networks. 6 The success of the trading soon led to a heated argument among both the members of the mission board and the supporters of the mission in Basel and Germany. Was it proper for a mission to engage in trade? Was not the propagation of the gospel to be its sole aim? By 1859 the trading activity was separated from the mission proper and given an organizational structure of its own, leading to the

${ }^{6}$ Giorgio Miescher, "Zu den Anfängen der Basler Missions-Handelsgesellschaft in Christiansborg (Ghana)" in Lilo Roost-Vischer, Anne Mayor, and Dag Henrichsen, eds., Brücken und Grenzen: Passages et Frontières (Münster, 1995), 360. The mission also sent a young, commercially experienced man to India with a view to create job opportunities for those converts who had been expelled from caste society. Here too the business expanded rapidly. Gustaf Adolf Wanner, Die Geschichte der Basler Handelsgesellschaft A.G. 1859-1959 (Basel, 1959), 32-34. 
establishment of the Basel Mission Trading Company as a shareholder society. But the company remained intimately linked to the mission and the tensions among the supporters of the trading and its opponents persisted. ${ }^{7}$

It was only in 1917 that the company was legally separated from the Mission and renamed the Basel Trading Company in an effort to prevent the British authorities from confiscating the assets of the company on the Gold Coast, Cameroon, and India, stressing the fact that the trading company was a fully Swiss-and thus neutral-enterprise. The British, however, saw the Basel Mission as a German organization. Most of the missionaries were German; the organization was heavily funded by Christians in southern Germany, and a German theologian traditionally held the position of its director. Due to its obvious proximity to the mission, the trading company too was considered to be German. Its new name did not prevent the confiscation of all its assets in the British colonies and their transfer to the Commonwealth Trust. While the trading company immediately took up the fight for the restitution of its belongings, it created the Union Trade Company and in 1921 made a new start on the Gold Coast.

This venture met with the same success as the former Basel (Mission) Trading Company. By the time the confiscated belongings of the Basel Trading Company on the Gold Coast were restored in 1928, the UTC had grown so big and had become so successful that the mother firm Basel Trading Company was turned into a holding. It was no longer directly involved in the trade but rather controlled an empire consisting of several independent companies operating in England, France, the United States, Ghana, Liberia, Nigeria, and Cameroon. Still, as from the very beginning, the company kept contributing financially to the evangelizing work of the Basel Mission. In the 1980s the holding had established a network of some eighty companies operating worldwide and in a wide mix of sectors: textiles, watches, jewelry, cosmetics, office communications, etc. But despite a turnover amounting to more than two billion Swiss francs in the early 1990s, the end was near. Many of the sectors the firm had invested in proved risky or unsustainable and with the dwindling of the sales in Africa, which was its principal market, this empire came to a sudden end. In 1999 the Union Trade Company ceased to operate.

7In 1884 Otto Schott, the director of the Basel Mission society, resigned from his post in order to express his opposition to this blending of evangelization and trade. Wanner, Geschichte, 83. 


\section{III}

At the height of its glory in the late colonial period, the commercial activities of the UTC included not only the sale of musical instruments and shellac records, but also the production of music. The following portrayal of the UTC's recording business is mainly based on oral information gathered from people who were involved in these activities, which are barely documented in the company's archives. Luckily I have been able to speak with two of the former employees of the UTC in charge of the recording business in the 1950s. These are Gerhard Kaegi who, after the break caused by World War II, started these activities again in 1954, and Walter Esposito who did the last recordings in 1957. In addition I traced two of the musicians who were recorded by UTC in those years: Samuel Kwabena Nyama, an Ashanti folk musician from New Asonomaso, who was recorded by Gerhard Kaegi in 1954, and Kwabena "King" Onyina from Kumasi, who did at least eight recordings with the company in 1956. This oral history is supplemented by research into both the recordings themselves and the scarce written documentation.

Soon after the introduction of the gramophone, the music industry spread around the world, including Africa. At first only recordings of European and American music were available. These foreign tunes met with a lot of interest but, in order to expand this overseas market for machines and records and to exploit the business opportunities fully, recordings of the local music had to be made. From around the turn of the century record companies sent their engineers to the most remote areas of the world in order to capture local music. ${ }^{8}$ When the Zonophone label did the first recordings of Ghanaian popular music in London in the late 1920s, the west African market experienced a boost and rapidly developed into a veritable Eldorado. ${ }^{9}$

The Union Trade Company was quick to join this booming industry. For its recording business it relied on the services of professional engineers of the Zonophone Regal label, which was to be the low-price label of the Electric \& Musical Industries Ltd (EMI). These recording engineers moved along the UTC trading network, making use of the company's facilities. Their activities came to an end in 1939 with the beginning of World War II. Not only did shipping the recordings to

8paul Vernon, "A Look at the Engineers who Made History Traveling the World Recording its Music," Vintage Jazz Mart 94(1994), electronic version (1997) at http://sunsite.kth.se/feastlib/mrf/yinyue/texts/vim_engineers.html.

9Paul Vernon, "Talking Machines Hit West Africa," FolkROOTS 122(1993), electronic version (1997) at http://sunsite.kth.se/feastlib/mrf/yinyue/texts/fr122savanna.html. 
England and the finished records back to Africa become more and more difficult, but the shellac became a raw material of strategic interest and was short in supply. Recording was started again only in 1954. This time the UTC, again responding to a huge demand for Ghanaian music, chose a different and "low budget" approach. It had one of its sales staff undergo brief training by EMI and sent him with a mobile recording unit to west Africa. This UTC employee, our Gerhard Kaegi, was to record for EMI and let the musicians sign contracts with EMI. They were paid in cash according to the EMI standards at that time. The mechanical rights for the recordings were thus with EMI and UTC only had the exclusive rights for their distribution. While the more prominent musicians like E.T. Mensah or King Onyina had their longterm contracts with Decca or Philips, they still liked to record with UTC from time to time, as this provided them with instant cash. In fact Kaegi remembered that he used to display the $£ 5$ at stake on his recording unit while the musicians played, after which payment followed immediately.

As in the 1930s these recordings were made along the UTC trading network. There was no recording studio available to UTC on the Gold Coast and makeshift studios had to be set up in the company's buildings. The poor acoustic conditions were improved by hanging carpets in front of the walls and other expedients. Only in Lagos could Gerhard Kaegi make use of the national radio studio when doing Bobby Benson's first recordings. 10 Otherwise he traveled from one regional UTC headquarter to the next, asking the company's employees whether they knew of any local band worth recording. These informants mostly brought forward bands or choirs in which a relative of theirs was performing. Often Kaegi simply recorded the bands that happened to perform in town on a particular evening.

The lack of a serious recording policy and adequate market research, together with the readiness and ability to do recordings under makeshift conditions, resulted in a great variety in styles of the music produced by UTC. Its catalog could be labeled as "democratic" in the sense that it represented the music performed and consumed by the people. The major disadvantage of UTC's approach was a rather poor quality of the recordings. When in 1957 Walter Esposito, a young employee of UTC who was himself an avid jazz musician and music

${ }^{10}$ See Bobby Benson, "Cherrycoco and Bebiji Topi Yo Sokotijimu," shellac record Parlophone UTC 3003 (London, 1954); idem, "La Castagnette and Portable Girl," shellac record Parlophone UTC 3004 (London, 1954); idem, "Shemiloya No.2 and Darling I Know What You Want," shellac record Parlophone UTC 3005 (London, 1954). 
lover, was charged with the recording business, he clearly expressed his dissatisfaction with the quality of the music produced. In order to be competitive and produce recordings befitting the high UTC reputation, he recommended that the company establish a professional studio. Failing that, recording activities should better be stopped altogether. Not sure about the company's future in an independent Ghana, the UTC board of directors refrained from major investments and chose to put an end to its recording activities. ${ }^{11}$

\section{IV}

When UTC ceased its operations all its archival holdings to 1948 were transferred to the archives of mission 21, the institution succeeding the Basel Mission. The UTC archives, besides the written documents, also contained a collection of 777 shellac records, which for some reason had ended up at Basel. Although most of the records were not pre1948 , the integral collection became part of the transfer. ${ }^{12}$ It consisted partly of new commercial shellac records that were kept for reference, and partly of so-called test records. Such test pressings were made from the tapes sent from Africa to EMI in order to evaluate the best strategy for the publication of a specific title or to assess whether it was worth publishing at all. The test records were sent back to Ghana and Nigeria, where local music connoisseurs listened to them and approved of their publication-or not. Often it would be recommended that a less attractive title be published as a side $\mathrm{B}$ to a hit title.

However, this leaves us with the question: how did these test records end up at Basel? Both test records as well as published records available at Basel do not seem in any way to represent the full UTC music production. All in all 727 different titles are featured. While 402 of the songs are available in published form on 218 commercial records, another 325 songs are represented in the form of test records only. ${ }^{13} \mathrm{As}$

11The recording activities, however, might have lasted later than 1957. I found one indication in the UTC correspondence that recording was still going on in 1958, when the UTC general agent in Accra commented on the sales estimates for that year. He reported that in comparison to the year 1957 a big portion of the "recording business" was lost, as the two most important "recording customers" had gone bankrupt. In 1957 the recording activity had comprised one-fifth of the turnover of the machinery department. UTC archives at WELINVEST, General-Agent Accra 1 July 1957-31 March 1959, Letter by General Agent H. Hintze to the Board of Directors at Basel, Accra 4 April 1959.

12We are thankful to Hans Buser, a former UTC employee, who played a crucial role in convincing the company's managers to transfer the collection to the public Basel Mission archives.

${ }^{13}$ This confusing play of numbers results from the fact, that several successful Downloadefffordings. Wers reissued, org/core. University of Basel Library, on 11 Jul 2017 at 12:07:31, subject to the Cambridge Core terms of use, available at https:/www.cambridge.org/core/terms. 
there is no supplementary documentation on the recording activity at both the UTC and mission 21 archives except for a rudimentary register, we seriously lack information on the recordings. ${ }^{14}$ In the case of any recording featuring among the published discs we know the artist's name, the title of the song, the language in which it was performed, the year the recording was made, the country, and sometimes even the place of origin. But for the music available on test records only, the information is more than sketchy. Here we neither know the title of the song, nor whether it was published at all. It is only the number of the recording which offers a key for further research. ${ }^{15}$

Considering the fact that the UTC record numbers (i.e., the individual number for each commercial UTC shellac disc) range up to about 6000 , and considering that each published disc features two songs, it is highly probable that UTC recorded far more music than that which is represented at the archives. ${ }^{16}$ Many or most of the songs available at Basel as test records only might have been published without these commercialized versions being available at the archives of mission 21 . As we have not gathered further information from the UTC catalogs or other documentation available at EMI, we cannot attempt to characterize the composition of the holding in any quantitative way, or to claim changes in the recording strategies over time with authority. What follows is an attempt to convey an idea of the diversity in the music featured in the collection and to raise some points of interest as well as some questions.

${ }^{14}$ It is planned to do research at the British Library Sound Archive, where copies of the UTC catalogs are kept and at the archives of EMI at Hayes. The latter are not public and access is limited.

${ }^{15}$ These recording numbers, also called PEG or matrix numbers, are displayed on every published record. Sometimes they are part of the paper label stuck to the disc, but mostly they are embossed in the lead-out area of the shellac disc. See Kwame Sarpong's contribution in this same volume.

${ }_{16}$ The record numbers available at Basel might hint to four different series of recordings. There are records with the numbers 2-94, 1001-1033, 3002-3049, 6001-6071. We have not been able to ascertain how the four different series of UTC record numbers come about. There is neither a significant correlation with the year or the place of production (and therefore with the recording engineer), nor with the numbers of the recordings or the style of the music. There are also some few shellac records published under the Odeon label in 1931 with numbers ranging between B43003 and B43133 and in 1936 with numbers ranging between A234002 and A234019. It is interesting to note that it is the B series that dates from an earlier year. This strengthens the point made by Wolfgang Bender below. 
According to Gerhard Kaegi, UTC's entry into the recording business on the Gold Coast was greatly influenced by the singing band movement of the 1920s and 1930s. This movement was rooted in the Presbyterian Church of the Gold Coast, of which the Basel Mission church was the precursor. One of its driving forces was Ephraim Amu, who was a teacher and catechist in the Presbyterian Church and had received his training at the former Basel Mission teacher-training institute at Akropong. Later he taught music at this institution until he lost his job due to his efforts to reconcile the Presbyterian Church culture with African culture. ${ }^{17}$ This singing band movement offered a new platform for Christians both to perform music outside the strict confines of the church and to Africanize church music, liberating themselves from the canon of European-style Basel Mission and Presbyterian Church hymns. The singing band format, according to Kwesi Sackey, originated in the Methodist congregations of the Fante region. There, as early as the mid-nineteenth century, bands singing in the Fante language were formed, in order to give a voice to non-English-speaking Christians. Earlier, the music in the church had only been performed by the official choir, whose members sang in English, thereby creating a class distinction within the congregation, based on education. The Fante lyrics (Ebibi-Ndwom) thus had a democratizing effect within the Methodist Church, enabling ordinary members to partake actively in the musical celebration of the service. While the singing bands received only a limited space to perform within the church service, they played an important role in Christian activities outside the church building such as wake-keepings during funerals and other celebrations. ${ }^{18}$

Not only did the movement have an enormous impact on the Ghanaian church culture, but it also seems to have extensively influ-

${ }^{17}$ Actually this opened the path to a second career as a musicologist, composer, and teacher at Achimota College and Legon University. Amu has left a huge number of compositions, many of them with nationalist lyrics. His famous "Yen Ara Asase Ni" composed in the 1920s, has become Ghana's unofficial national anthem and has played an important role in creating a national feeling. See "Akropong Singing Band, Yen Ara Asase Ni," shellac record Parlophone UTC89 (London, 1931); Kojo T. Vieta, The Flagbearers of Ghana (Accra, 1999), 438, 443. See Fred Agyemang, Amu the African: A Study in Vision and Courage (Accra, 1988).

${ }^{18}$ Chrys Kwesi Sackey, Highlife: Entwicklung und Stilformen ghanaischer Gegenwartsmusik (Münster 1995), 379-83. See also Veit Arlt, "Der Tanz der Christen: Zu den Anfängen der populären Musik an der Goldküste, ca. 1860-1930," Jabrbuch für Europäische Überseegeschichte 4(2004), 157, 157n24. 
enced the development of popular music in Ghana. ${ }^{19}$ This becomes evident when looking at the singing band music featured in the UTC collection. Of the 95 records dating from the year 1931, 61 bands call themselves a "singing band." This prevalence seems to confirm the point Gerhard Kaegi made on the importance of the Christian singing band movement for the beginning of the UTC recording activities in the 1930s. However, the label "singing band" was not used by Christian vocal ensembles alone, but also by Muslim ones and sometimes by decidedly secular guitar bands. ${ }^{20}$ Beyond the vagueness of the term "singing band" something else becomes apparent here, and this is the nexus "Christianity and popular music" treated by John Collins below.

The UTC, however, in no way confined itself to Christian music. Three examples from among the early recordings illustrate the recording engineers' readiness to record any kind of music that might sell. These are two recordings of the Asantehene's "Kwadwomfo," two recordings of the "Ga Manche's women choir," and two songs by the Ashanti folk musician Kwami Tua. The larter was a prominent but controversial figure in the aftermath of the Yaa Asantewa war. As a mission-educated person with a royal family background, he became an important partner of the British in Kumasi. His contemporaries, however, complained bitterly that he was handling his appointment in a corrupt and bullying way. ${ }^{21}$ In these two recordings Kwami Tua, who was both a noted court musician and a satirist, plays an accordion and his songs are a fascinating fusion of Ashanti musical tradition with the modern music from the coast. The recordings by the women's choir of the paramount chief of Accra and by the Ashanti king's executioners illustrate that the recording team seems to have in no way felt obliged to record Christian music only, but recorded whatever came its way or whatever there was a demand for. ${ }^{22}$ The case of the Kwadwomfo, however, is intriguing. When I played this recording to Kwabena Nyama, the old man was struck by horror and amazement. It has to be asked who might have wanted to buy this music, the original sound of which

${ }^{19}$ Sackey, Highlife, 405, describes how dance band Highlife artists such as Ebow Taylor adapted the Ebibi-Ndwom as a dance music turning its 12/8th into a 4/4th rhythm.

${ }^{20}$ Fourteen of the singing bands recorded in 1931 were Muslim bands. See, for example, Mallam Katsina Singing Band, "Hausa Song," shellac record Parlophone UTC54 (London, 1931). For a guitar band see Mpraeso Singing Band, "Meyere Reton Cocoa," shellac record Parlophone UTC57 (London, 1931).

${ }^{21}$ See Tom McCaskie, State and Society in Pre-Colonial Asante (New York, 1995), $216,286,411 \mathrm{n} 98$.

22In the Basel Mission tradition everything connected to chieftaincy was ,heathen” per se and these two recordings would never have found the consent of an earlier generation of Basel Missionaries. The Ghanaian church leaders up to this day suffer from these early teachings. 
signaled utmost danger. ${ }^{23}$ Other band formats featured in the archives are the trios, the most famous among them being Jacob Sam and his "Kumasi Trio."24 Other trios are the Essikuma Trio and the Fanti Opim Trio.

When considering the value of these recordings as texts or documents for the study of African history and cultures, we have to bear in mind that the trios, and the guitar bands that later developed from them, were mostly performing theatre shows, so called "concert parties"-the Ghanaian popular theatre-opera format. Many of their songs were part of traveling theatre performances, which took news, fashions, and debates to even the most remote parts of the colony. Therefore their texts are an important source for the study of Ghanaian societies and their histories. ${ }^{25}$ In these plays women did not enter the stage until recently, and men performed their roles, dressing as drag queens and singing in falsetto voices, thereby creating an ideal of highpitched male voices that persists in Highlife to this day. ${ }^{26}$ The UTC collection, however, contains one very interesting set of recordings of the famous Appiah Adjekum's guitar band that highlights the important role women could play in the music business. At least two of the six recordings of the band made in 1954 were directed by Mrs. Korkoi Adjekum and, according to the information received from Gerhard Kaegi, she proved to be a very self-confident director and musician who was not easily satisfied with the quality of the sound produced by the band. 27

Among the UTC recordings we also find music from the north sung in the Fra-Fra, Dagomba, Grunshie, and Moshi languages. For 1939, for example, 14 songs are performed in these northern languages, while there is a prevalence of Christian singing bands with 51 out of 119 titles. When UTC set out to do recordings in Nigeria in 1954, the number of bands singing in the Hausa language increased even further. The same year also saw the rise of the swinging dance band format and, out of 103 Ghanaian recordings, 21 feature dance bands, most of them

${ }^{23}$ According to Kwabena Nyama if ever you heard this sound in the olden days you knew that you were about to be executed.

${ }^{24}$ Unfortunately these very recordings, six in number, are missing in the collection.

${ }^{25}$ See, for example, Kwabena N. Bame, Come to Laugh. African Traditional Theatre in Ghana (New York, 1985); Karin Barber, John Collins and Alain Ricard, West African Popular Theatre (Bloomington, 1997); Catherine M. Cole, Ghana's Concert Party Theatre (Bloomington, 2001).

${ }^{26}$ The falsetto voice of course was also used for acoustic reasons, as it carried the sound much further than the ordinary voice and was important before electric amplification came into use.

27Korkoi Adjekum's Band, "Mmerantesem Nnti and Gye Me Tataa," shellac record Parlophone UTC6023 (London, 1954). 
reserve bands of E.T. Mensah, the "King of Highlife." 28 Among the 98 Nigerian recordings there are 12 dance bands, the most prominent artist being Bobby Benson. In 1956 the guitar bands take the lead, a development that is even more pronounced in the last batch of recordings of 1957 . This may be read as a sign that UTC, with its simple setup, could no longer compete with other recording studios and had to concentrate on less prestigious or low budget guitar bands. ${ }^{29}$

In fact, it is exactly this low-budget approach and lack of professionalism in the selection of the bands that makes the UTC records at the archives of mission 21 so unique and so valuable as a source. It has resulted in a collection that captures the whole variety of popular music of Ghana and Nigeria during those years. Hausa praise-singers from the north of Nigeria, the brass band of the West African Frontier Force, the jazzy high-class dance bands, traditional performers, Sunday schools singing church music, singing bands performing Africanist art music compositions, folk musicians, "traditional" performers from the court, and many more are represented and give us an insight into a very creative epoch in which foreign and local resources were tapped, while shaping a new and independent musical idiom.

\section{VI}

Today all these records are stored at the archives of mission 21..Many are largely unused commercial records and what makes the collection even more interesting is the fact that mission 21 has a very liberal archival policy, although presently access is still limited, since there is neither the staff nor the infrastructure to make for a safe usage of the recordings. Furthermore about half of the titles are available on test records only, the use of which needs special care, knowledge, and hardware. This is why we have set out to digitize the whole of the collection, as a first step making the music available to visitors to the archive on recordable compact discs, with a view to make them accessible worldwide through a website in the future.

In order to study the feasibility of this plan, assess the quality of the recordings contained in the collection, and gain the necessary expertise, we have produced the compact disc "Ghana Popular Music, 19311957. From Palm Wine Music to Dance Band Highlife" which was

${ }^{28}$ John E. Collins, E.T. Mensab: King of Highlife (Accra, 1996).

${ }^{29}$ The guitar bands and their concert party popular theatre developed from the trios mentioned above. It was E.K. Nyame who pioneered the new, bigger format. See John E. Collins, Highlife Time (Accra, 1994), 11. 
published in 2001.30 The disc contains examples of all the different music styles from southern Ghana featuring in the collection and is accompanied by a booklet providing an introduction to the popular music of Ghana, with commented translations of the songs. The text of this booklet results from cooperation with the University of Ghana in the person of John Collins. The production has allowed establishing connections to an important international network consisting of institutions and specialists concerned with similar projects. In the course of the project we have also created an electronic inventory of the collection and have digitized 113 of the recordings. Sets of digital copies on recordable compact discs have been transferred to several public archives in Ghana on the occasion of our CD-launch at Accra on 4 January 2002, and are now available to the interested public. Copies of our commercial compact disc were widely distributed to the Ghanaian media in order to make the music available to the whole of the population through radio without violating the copyright laws. Further copies of the 113 digitized titles have been deposited with the archives of mission 21 and the Swiss national sound archives, Fonoteca Svizzera.

For the continuation of our project we have proposed proceeding with the same twofold strategy. We want to render the music accessible as a resource for students and researchers here and in the countries of origin as a set of recordable compact discs, which can be accessed at the archives. Moreover, we want to produce another two commercial discs, which will allow us to alert the general public, to make at least part of the music available on the airwaves, and-last but not least-to help in raising funds for this project. Each production will include the digitization of 100 titles and will again be based on cooperation with partners in Ghana and Nigeria leading to exchanges, research seminars, and music workshops. ${ }^{31}$ As a third and ultimate step the collection will be made accessible on the Internet. At first an online searchable database is planned to which sound clips and any kind of further information (translations of lyrics, visual materials and cross-references of all sorts) can be added. In this respect we are monitoring closely the project of the Gramophone Records Museum at Cape Coast.

${ }^{30}$ Veit Arlt and Serena Dankwa, "Ghana Popular Music 1931-1957: From Palm Wine Music to Dance Band Highlife," compact disc Arion ARN64564.

31 In December 2002 we organized a theme week entitled "West African Pop Roots" at Basel that combined music workshops, concerts, lectures, and the symposium at which these papers were presented. We were able to invite Kwabena Nyama and his band, as well as John Collins and Aaron Bebe Sukura from the Local Dimension Band based at the University of Ghana. 